\title{
Late Realized ADHD with Severe Social Consequences
}

\author{
John E Berg* \\ Faculty of Health Sciences, Oslo and Akershus University College, Norway
}

Submission: September 16, 2017; Published: October 17, 2017

*Corresponding author: John E Berg, Senior Consultant in Psychiatry, Faculty of Health Sciences, Oslo and Akershus University College, PO Box 4, St. Olavs plass, 0130 Oslo, Norway, Tel: 0047 67235000; Email: john@pong.no

\section{Introduction}

Neurological diseases may co-occur with several mental disorders. The impact of mental disorders on the treatability of neurological disorders may not be clear-cut, and the differential diagnostic acuity of the clinician may be blurred. Attention deficit and hyperactivity disorder (ADHD), both in children and adults, may reveal itself mixed with mood disorders and substance abuse disorders [1]. The co-occurrence of all three groups of disorders is rare, but the diagnosis of one should alert the physician of the others. Most frequent co-morbid psychopathologies with ADHD include mood and anxiety disorders, substance use disorders, and personality disorders [2]. Late diagnosis of ADHD is according to my knowledge a rare occurrence and such a case is presented.

Case

A woman aged 47 contacted a neurologist for suspected migraine headache. She grew up as a restless child with both parents and performed poorly in school despite good intellectual capabilities. Social relations were difficult and she entered into conflict with more than ten consecutive partners. Her different jobs also ended after a shorter period with seemingly effective and skilful performance. Relations were easily started, and some have lasted for many years. Some degree of substance abuse may be interpreted as self-medication. After her last cohabitation with a partner ended, she currently lives with her parents. They are both old and hardly cope with her behaviour.

The neurologist proposed effective medical treatment for her migraine headaches. A chiropractor collaborating with her augmented the treatment with guided neck and shoulder manipulation. Her difficult behaviour and outbursts continued also in the office of the neurologist.

A consulting psychiatrist sitting in during a session with the neurologist and chiropractor followed up with a separate consultation with her. After this consultation it was obvious to him that she must have had an untreated full-blown ADHD for years. After the first two tablets of methylphenidate she completely changed behaviour. And her migraine and neck pain also improved. Her appearance a month after was one of calm, although her vivid personality was still present.

\section{Discussion}

The present case illustrates the differential diagnostic problems encounter with comorbid disorders. Patients may present themselves to specialists not trained in discovering traits from other diagnostic entities, or they run solo private practice where the focus is more limited. A delay of more than 30 years before a correct and treatable illness is diagnosed would be rare. The mixture of symptoms may have contributed.

Substance-related problems are observed in patients on ADHD medication, but the use of ADHD medication reduced the rate of substance abuse by some $30 \%$ in a study of almost 3 million health care claims [3]. The present case would then probably not increase her substance abuse as her general wellbeing increased starting with methylphenidate. In adults atomoxetine is also shown to give a comparable stabilising effect on wellbeing [4]. Onset of a calming effect is quicker with methylphenidate than with atomoxetine. Collaboration with clinicians from other specialities would be recommended. Adherence to existing guidelines does apply [5].

\section{References}

1. Regnart J, Truter I, Meyer A (2017) Critical exploration of co-occurring attention-deficit/hyperactivity disorder, mood disorder and substance use disorder. Expert Rev Pharmacoecon Outcomes Res 17(3): 275-282.

2. Katzman M, Bilkey T, Chokka P, Fallu A, Klassen L (2017) Adult ADHD and comorbid disorders: clinical implications of a dimensional approach. BMC Psychaitry 17: 302-317.

3. Quinn P, Chang Z, Hur K, Gibbons RD, Lahey BB, et al. (2017) ADHD medication and suvstance-related problems. Am J Psychiatry 174(9): 877-885.

4. Carpentier PJ, Levin FR (2017) Pharmacological treatment of ADHD in addicted patients: What does the literature tell us? Harv Rev Psychiatry 25(2): 50-64.

5. Matthys F, Soyez V, van den Brink W, Joostens P, Tremmery S, et al (2014) Barriers to implementation of treatment guidelines for ADHD in adults with substance use disorder. J Dual Diagn 10(3): 130-138. 


\section{Your next submission with Juniper Publishers will reach you the below assets}

- Quality Editorial service

- Swift Peer Review

- Reprints availability

- E-prints Service

- Manuscript Podcast for convenient understanding

- Global attainment for your research

- Manuscript accessibility in different formats

( Pdf, E-pub, Full Text, Audio)

- Unceasing customer service

Track the below URL for one-step submission https://juniperpublishers.com/online-submission.php 